\title{
THE CONTRIBUTION INCOME, INVESTMENT RESULTS, AND CLAIM EXPENSES ON SHARIA LIFE INSURANCE INCOME
}

\author{
Laila Mardiyah Nainggolan ${ }^{a}$ \\ Andri Soemitrab \\ apostgraduate Master, Faculty of Islamic Economics and Business, Universitas Islam Negeri \\ Sumatera Utara \\ 'Islamic Economics, Faculty of Economics and Islamic Business, Universitas Islam Negeri \\ Sumatera Utara \\ Email: lailamardiyah1213@gmail.comª andrisoemitra@uinsu.ac.id
}

\section{ARTICLE HISTORY}

Received:

31 August 2020

Revised:

30 October 2020

Accepted:

7 December 2020

Online available:

11 December 2020

Keywords:

Contribution Income, Investment Results,

Claim Expenses,

Profit,

Sharia Life Insurance

*Correspondence:

Name:

Laila Mardiyah Nainggolan

E-mail:

lailamardiyah1213@gmail.com
ABSTRACT

This study aims to examine the effect of Contribution Income Investment Results and Claim Expenses on Sharia Life Insurance Profits in Indonesia for the 2012-2019 period. This research is a quantitative study with secondary data in the form of Islamic financial reports and the sample selection using purposive sampling. The amount of data is 13 companies with eight years of observation to obtain 104 observational data which are sampled in this study. The technique used is panel data regression analysis technique, with analysis of hypothesis testing, namely the $t$ test and $F$ test. The results show that contribution income partially affects the profit of Islamic life insurance, the investment results also affects the profit of Islamic life insurance, if the fund invested are large, the investment returns will be large so that the profit will be high. Furthermore, claim expense partially affects the profit of sharia life insurance, the claims will reduce the amount of funds to be invested by the company, at the end it reduces the company's profit. Based on $\mathrm{F}$ test, all variables simultaneously influence the profit of Islamic life insurance. The suggestion is that, in order to increase the profitability of Islamic insurance, the company Islamic insurance needs to consider the investment process, also to increase the underwriter analysis to mitigate the excess of expenses from claims.

\section{INTRODUCTION}

Insurance is coverage that is used as a form of an effort to reduce risk. Judging from its general meaning, this insurance practice is related to the age of human life. A person's life is full of risks, so humans seek solutions to these problems to minimize their impact. Currently, Indonesia has two insurance systems / concepts, namely conventional and sharia systems. In Indonesia, the conventional system is the first to 
be recognized. Over time, because the majority of Indonesian people are diverse in Islam and the level of religious awareness has increased, the perspective on Islamic insurance in Indonesia is increasingly promising.

1994 was the first year that Indonesia had sharia insurance as evidenced by the establishment of the general takaful insurance company and family takaful insurance, most of whose shares belonged to Syarikat Takaful Indonesia. Sharia Insurance (ta'min, takaful or tadhamun) in the MUI DSN Fatwa No. 21 / DSN-MUI / III / 2002 is an effort to protect each other and help among a number of people / parties through investment in the form of assets and / or tabarru' which provides a pattern of return to face certain risks through a contract (agreement) in accordance with sharia. The contracts that are in accordance with the sharia are those that do not contain gharar (fraud), maysir (gambling), usury, zhulm (persecution), risywah (bribes), haram and immoral goods.

Although the sharia insurance industry has developed, this has not yet been able to compete with conventional insurance companies in terms of market share. The penetration of sharia insurance in the national industry for the 2016 period was still low, namely at $0.098 \%$. Meanwhile, Conventional Insurance reached $99.902 \%$. According to Hasbi and Suryawardani (2013) low penetration conditions indicate problems with sharia-based financial instruments. There are two possible factors causing the problem. The first factor is that the Islamic insurance product is not attractive. The second factor is due to the low performance of sharia insurance companies so that people still do not believe in sharia-based insurance. According to Ambarwati and Hasib (2018), one of the main indicators used as the basis for health assessments is financial statements. Therefore, Islamic insurance must make improvements, including by maintaining financial performance.

The development of Islamic companies in Indonesia from 2012 to 2019 has increased. There are 62 insurance companies by the end of 2019. The following is the growth data for insurance and reinsurance companies with the sharia business:

Table 1

Growth of the Insurance Industry on a Sharia Base 2012-2019 Period

\begin{tabular}{|c|c|c|c|c|c|c|c|c|}
\hline Description & 2012 & 2013 & 2014 & 2015 & 2016 & 2017 & 2018 & 2019 \\
\hline Sharia Life Insurance Companies & 3 & 3 & 3 & 5 & 6 & 7 & 7 & 7 \\
\hline $\begin{array}{l}\text { Sharia Non-Life Insurance } \\
\text { Companies }\end{array}$ & 2 & 2 & 2 & 3 & 4 & 5 & 5 & 5 \\
\hline Sharia Reinsurance Companies & 0 & 0 & 0 & 0 & 1 & 1 & 1 & 1 \\
\hline $\begin{array}{l}\text { Sharia Unit of Life Insurance } \\
\text { Companies }\end{array}$ & 17 & 17 & 18 & 19 & 21 & 23 & 23 & 23 \\
\hline $\begin{array}{l}\text { Sharia Unit of Non-Life Insurance } \\
\text { Companies }\end{array}$ & 20 & 24 & 23 & 24 & 24 & 25 & 24 & 24 \\
\hline $\begin{array}{l}\text { Sharia Unit of Reinsurance } \\
\text { Companies }\end{array}$ & 3 & 3 & 3 & 3 & 2 & 2 & 2 & 2 \\
\hline Total & 45 & 49 & 49 & 54 & 58 & 63 & 62 & 62 \\
\hline
\end{tabular}

Source: Financial Services Authority 
The table above shows the progress of Islamic principle insurance companies has increased. In 2012, the number of sharia insurance companies reached 45 companies and in 2019, it increased to 62 company units. It is known that there are 7 sharia life companies, while there are 5 sharia general companies, 1 sharia reinsurance company, 23 sharia unit life companies, 24 sharia unit general insurance companies, and 2 sharia reinsurance companies.

The growth in the number of companies is supported by the increasing profit of insurance companies. Profit, according to Harahap (2008) namely revenue between realized income originating from company transactions in a certain year deducted from expenses for earning that income in a particular year. Profit is an effort to make efficiency as well as capital, the main strength owned by the company to maintain the existence of the company today and for the future, profit between the initial capital is used for the operation of the company, profit, including the initial capital that guarantees workers' letters and profits, also includes capital to attract third parties to invest in a company.

Meanwhile, according to Marwansyah and Utami (2017), profit is one of the main goals of a company in carrying out its activities. Earnings information is presented by publishing financial reports and is used to estimate the efficiency of company performance. Companies with high earnings quality have a better performance than companies with lower level of earnings quality.

The point is that profits are obtained for the good performance of the company itself. Therefore, it is very valuable and significant that measurements are made for the company, whether related to the company's internal or external parts that can have an influence on the company. Profit is identical to the measurement of the company's financial financing performance, but the main aspect is to present a description of the financial health condition of a company so that it will provide information about financial health for managers and investors. The following is the growth of Islamic life insurance as seen from the growth in contributions, investments, claims and profits:

Table 2

Growth in Contribution, Investment, Claims and Profits for Sharia Life Insurance Companies (In Trillion Rupiah)

\begin{tabular}{lrrrrrrrr}
\hline Information & \multicolumn{1}{c}{$\mathbf{2 0 1 2}$} & \multicolumn{1}{c}{$\mathbf{2 0 1 3}$} & \multicolumn{2}{c}{$\mathbf{2 0 1 4}$} & $\mathbf{2 0 1 5}$ & $\mathbf{2 0 1 6}$ & \multicolumn{1}{c}{$\mathbf{2 0 1 7}$} & \multicolumn{2}{c}{$\mathbf{2 0 1 8}$} & $\mathbf{2 0 1 9}$ \\
\hline Contribution & 5,20 & 7,19 & 8,39 & 8,27 & 9,44 & 11,09 & 12,66 & 16,70 \\
Investment & 9,09 & 11,54 & 16,40 & 19,60 & 24,32 & 30,40 & 31,87 & 39,85 \\
Claim & 1,24 & 1,69 & 2,20 & 2,58 & 3,06 & 3,50 & 7,19 & 10,60 \\
Profit & 880.873 & 1.023 .917 & 1.453 .942 & 1.641 .673 & 1.545 .291 & 1.496 .307 & 1.514 .275 & 2.808 .526 \\
\hline
\end{tabular}

Source: Financial Services Authority (2019)

From the table above, it can be illustrated in a graphical way that the profit development of Islamic life insurance is influenced by the number of contributions, investments and company claims in Indonesia: 


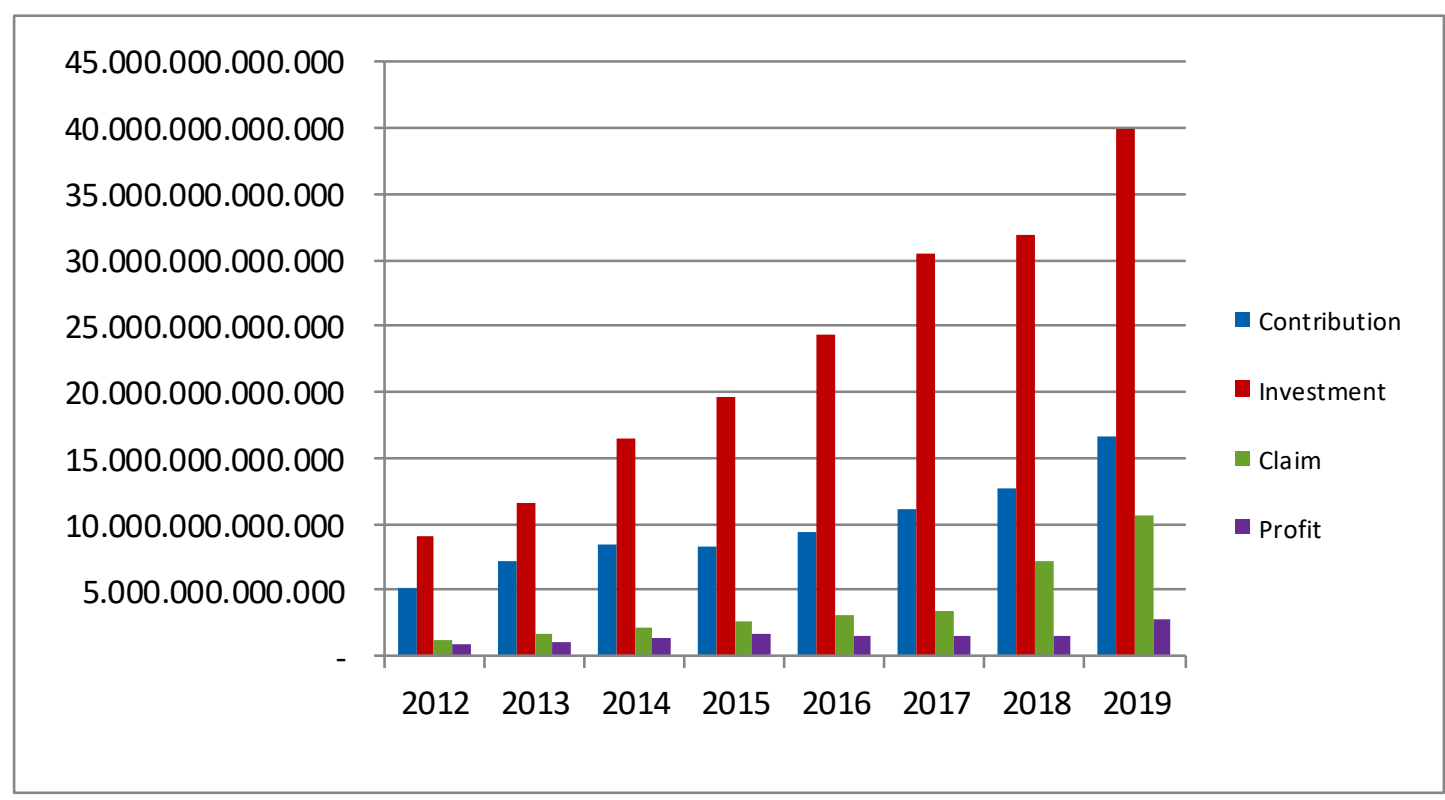

Figure 1. Total of Contributions, Investments, and Claims of Sharia Life Insurance Companies for 20122019 (In Trillion Rupiah)

Source: Processed data (Financial Services Authority, 2019)

Figure 1 shows that the contribution of Islamic life insurance companies has fluctuated. In 2016 the number of contributions increased, but in the same year the amount of profit decreased, this situation is out of sync with the theory which explains that contribution income is the biggest factor influencing insurance company profit Andre Soemitra (2009). In 2019 the number of claims increased while the number of company profits also increased, logically if the claims submitted by the insured were high, then the profits obtained by the company would decrease.

The ups and downs of company profits come from internal factors in the insurance company. It means that the factors come from within the company itself, namely the income and expenses that the insurance company earned and budgeted for. The revenue (income) of insurance companies, according to Salim (2007), starts from premium income, acquisition of investment, payment of fines and anti-loss. The expenses come from claim payments, salaries or wages, claim realization costs, or tax income.

The first factor is the revenue factor which is considered to be able to influence the insurance company's profit, namely the contribution / premium receipt. Contribution or premium is the gross amount that is the responsibility of the participant for the portion of risk and ujrah (IAI, 2016). In sharia insurance, premium is obtained from the amount of funds paid by the members of the Islamic insurance to the management after paying administrative costs including operational costs. The contribution income is then combined with the tabarru' fund to be managed by the company. 
According to Ciurel (2000) The insurance premiums must be adequate, which means that for a group of contracts, the money collected from policyholders plus the interest generated from the investment, this amount must be sufficient to pay all promised amounts and cover the insurance company budget, the insurance premiums should be fair that the risk that each insured person takes into account and the insurance premiums should not be excessive compared to the amount insured. A scientific study conducted by Sastri et al. (2017) explains that premium income has a positive and significant effect on the profit of an insurance company, while research by Reschiwati and Solikhah (2018) reveals that premium income has no significant effect on the profit of an insurance company.

The factor of acceptance (income) is considered to affect the profit of the insurance company. The second is the investment result. A sharia-based insurance company is very urgent to invest in its assets to meet the decisions on which funds to be managed. Some insurance companies prioritize investment returns in overcoming the shortage of premium payments to be paid to insurers.

Investment is investing or placing assets, either in the form of assets or funds in something that is expected to provide income or will increase its value in the future (Sula, 2004). In this case, as an effort to maintain a balanced or stable fund even as it develops, in this case the company carries out an activity known as investing. Amrin (2011) adds that another profit that a company can have is the result of customer savings fund investment activities as well as underwriting surplus and investment returns from capital funds.

Wijaya (2013) states that investment returns partially have a weak relationship with insurance company profits, while research by Sastri et al. (2017) states that investment returns have a positive and significant effect on insurance company profits.

The next factor that affects the profit of the insurance company is the expenditure factor. One of the expenditure factors that affect the profit of the insurance company is the claim expense. Claim expense describes the costs incurred by the insurer as responsibility for maintenance provided to the insured in accordance with the risks that have been previously insured.

According to Sula (2004) a claim is an application provided for participants in obtaining coverage for losses they receive which are adjusted to the agreement. The claim describes the process by which participants are entitled to their rights under an existing agreement. All efforts made to bear all rights, are fully and properly respected. According to Saniatusilma and Suprayogi (2015), insurance claims are the right of insurance members and on the other hand, it is imperative for insurance companies to be bound by contracts. One of the basics of the sharia insurance business is the sharing of risk between members and companies in protecting their members. The increase in the total claim expense of an insurance company indicates the amount of funds spent to cover claims and benefits to the insured. If the total 
cost of claims is higher than the receipt of contributions, the company's financial statements show a negative amount in the profit post or reduce the company's profit receipts. Saputro (2019) states that partially claim expenses have an effect on profits, while Marwansyah and Utami (2017) states that claim expenses do not have significant effect on profits.

This research is interesting to study, namely a decrease in the profit of sharia life insurance companies and sharia life insurance units from 2016 to 2017, an increase in the number of investment returns in 2017 but in the same year company profits decreased and there were differences in the results of the conclusions in previous studies.

Based on the above introduction, this research formulates the following problems:

(1) How is the influence of contribution income to the profit of sharia life insurance for the period 2012-2019 partially? (2) How does the investment return affect the profit of sharia life insurance for the period 2012-2019 partially? (3) How is the effect of claim expenses on the profit of sharia life insurance for the period 2012 2019 partially? (4) How do the contribution income, investment return and claim expense influence the profit of Islamic life insurance for the period 2012-2019 simultaneously?

Overall, this research aims, namely: (1) To determine and test the effect of income contribution on the profit of Islamic life insurance partially. (2) To determine and test the effect of investment returns on the profit of Islamic life insurance partially. (3) To determine and test the effect of claim expenses on the profit of sharia life insurance partially (4) To determine and test the effect of contribution income, investment returns and claim expenses on the profit of Islamic life insurance simultaneously.

\section{LITERATURE REVIEW}

Yanggo (2003) argues that the main character of insurance is to provide protection to one another, and to provide mutual assistance to one another or known as "ta'awun". The principle of providing mutual assistance to one another is based on ukhuwah Islamiyah between members of Islamic insurance in dealing with problems (risks).

In the Al-Qur'an, there are several concepts that underlie Islamic insurance, namely the urge to prepare for the future, orders to help each other and cooperate, forbidding usury, forbidding maysir, forbidding eating in a false way, the mandate of Allah to be trustworthy and optimistic in tawakal, the appreciation of Allah SWT for noble deeds by humans (Puspitasari, 2015).

In today's modern society, life insurance has become a necessity. The demand for life insurance in Indonesia continues to increase in line with increasing income and public awareness of the importance of risk prevention. To meet these needs, a 
number of life insurance companies is constantly improving and developing products that will be marketed to the wider community.

Purwosutjipto (1999) life insurance is a reciprocal agreement between the cover (taker) of the insurance and the insurer, and the cover (taker) of the insurance binds himself during the course of the insurance to pay premiums to the insurer, while the insurer is a direct result and the death of the person whose life is insured or the expiration of an agreed period of time, commit themselves to pay a certain amount of money to the person designated by the insurance taker as the beneficiary.

Syahatah (2006) concluded that life insurance is an agreement between the owner and the insurance company, which is binding as long as the insurance pays the premiums to the insured, then the insurer is responsible for the premiums which will later be given to someone who is insured due to death.

So, sharia life insurance is a business that is used to protect and help each other between a number of people through investment activities in the form of assets and / or tabarru' which provides a pattern of returns to fight certain risks through an agreement in accordance with sharia.

Profit according to Soemitra (2009) is the income between the realization of income from company transactions in a certain period minus the costs incurred to get that income in a certain period. The insurance company obtains its profits from the profit sharing of participant funds which is developed on the principle of mudharabah (profit sharing system). The profit is divided based on the proportion or agreement that has been agreed. Profits obtained from Islamic insurance companies are from premium income and investment returns.

Contributions or premiums are the amount of money paid by a policyholder to an insurance company in connection with the insurance agreement set forth in the insurance policy (IAI, 2016). There are two elements of contribution to sharia life insurance, namely savings funds and tabarru' funds, while in general sharia insurance there is only tabarru' funds in the contributions paid by participants.

The accumulated contribution payments in each insurance company results in billions of rupiahs. So, for insurance companies it is very important to invest in existing assets to meet the needs for managed funds. Most insurance companies depend on the proceeds of their investment to cover the shortfall in contribution costs paid to the insured. Investment returns are the results obtained from participant funds in the form of tabarru' funds and savings managed by the insurance company as the manager. In this case, the participant / customer is the funder, and the insurance company is the mudarib (fund manager). The return on investment in participant funds will increase the participant's fund account balance in the underwriting surplus report before deducting the manager's right as mudarib. The investment return is the gross amount prior to issuance of the manager's rights over the investment return. The manager's right to investment returns is measured based on the agreed yield sharing (ratio) and is recognized as a deduction from the investment return. The manager's rights to investment returns are presented in the 
underwriting surplus deficit report as part of the manager of investment returns (Bayinah et al., 2017).

The next factor that affects the profit of the insurance company is the expenditure factor. One of the expenditure factors that affect the profit of the insurance company is the payment of claims or claim expenses. Claims are the rights of each member that the insurance company must provide according to the agreement in the contract (Sholihin, 2010). Claim costs incurred come from the tabarru' fund account, which is a fund account to help all participants who from the start have been sincerely committed by the participant to the needs of others, if someone is destined to die or get a disaster, accident, health problem and so on.

\section{Hypothesis}

\section{The Influence of Contribution Income on Sharia Life Insurance Profits}

Contribution or premium is a payment of an amount of money made by the insured party to the insurer to compensate for a loss, damage or loss of profit expected as a result of an agreement for the transfer of risk from the insured to the insurer (transfer of risk) (Amrin, 2006) whereas according to PSAK 108 , contribution is the gross amount that is the responsibility of the participant for the portion of risk and ujrah (IAI, 2016).

Sastri et al. (2017) state that contribution income has a positive and significant effect on the profit of sharia life insurance companies, while research by Reschiwati and Solikhah (2018) states that premium income does not have a significant effect on the profit of sharia life insurance companies.

Ho1 : Contribution income has no effect on the profit of Islamic life insurance

Ha1 : Contribution income affects the profit of Islamic life insurance

\section{The Influence of Investment Results on Sharia Life Insurance Profits}

Bayinah et al. (2017) argues that investment returns are the results obtained from participant funds in the form of tabarru' funds and savings managed by an insurance company as the manager, this investment returns are the gross amount before the management rights are issued on the investment return.

Research by Sastri et al. (2017) states that investment returns have a positive and significant effect on insurance company profits, while Wijaya (2013) states that investment returns partially have a weak relationship with insurance company profits.

Ho2 : Investment results have no effect on the profit of Islamic life insurance

Ha2 : Investment results have an effect on the profit of Islamic life insurance 


\section{The Influence of Claims Expenses on Sharia Life Insurance Profits}

Claims are regulated in PSAK 108, in theory, claims are the rights of insurance participants that must be provided by the insurance company in accordance with the contract that was agreed at the beginning of the agreement (IAI, 2016). The high number of claim expenses of an insurance company indicates the amount of funds spent to cover claims and benefits to the insured. If the total claim expense is higher than the contribution/premium income, then it is clear that the company's financial statements show a negative amount in the profit post or reduce the company's profit.

Saputro (2019) states that partially claims expense has an effect on insurance company profits, while Marwansyah and Utami (2017) research states that claim expenses have no significant effect on profits.

Ho3 : Claims expense has no effect on the profit of Islamic life insurance

Ha3 : Claims expense affects the profit of Islamic life insurance.

\section{Conceptual Framework}

Independent Variable

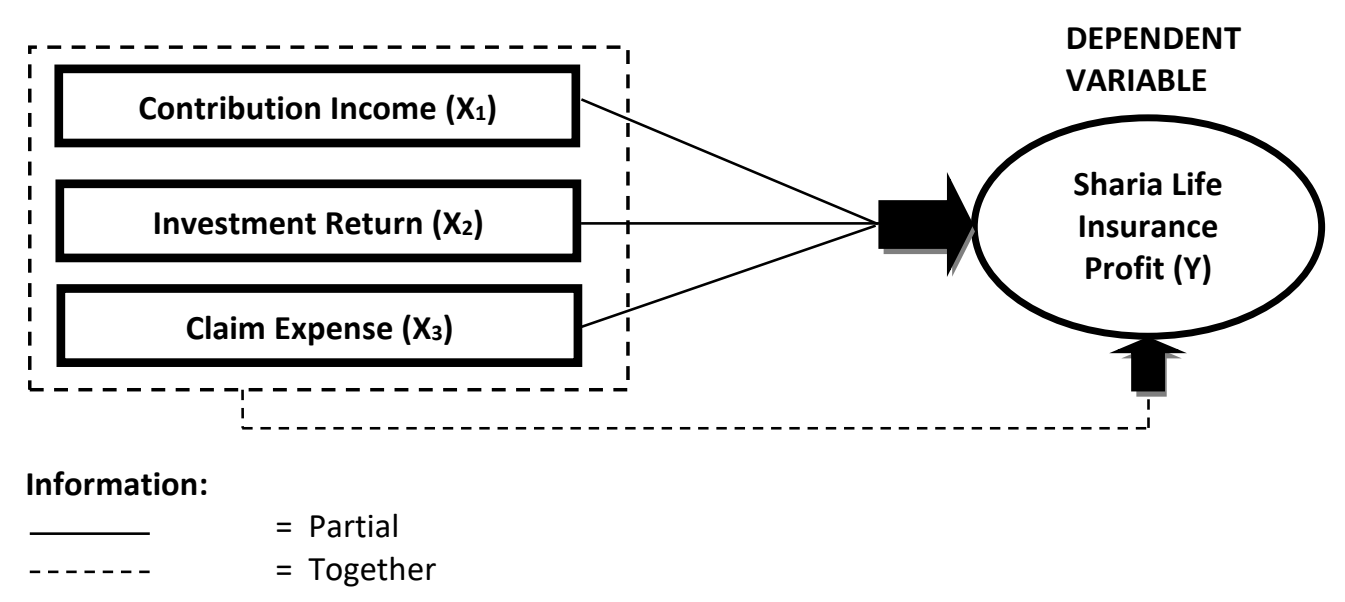

\section{RESEARCH METHODS}

This research includes quantitative research. Quantitative research is a research that uses numerical data analysis (Hendryadi, 2015). Quantitative data are in the form of numbers which are indicators that affect the profit of Islamic life insurance, namely in the form of profit data, total contribution income, total investment result and total claim expenses.

The population in this study is a sharia life insurance company in Indonesia which is registered with the Financial Services Authority (Bahasa: OJK). The sampling method in this study is purposive sampling method, which is a sampling method based on certain considerations (Sanusi, 2011). The sample selection process is a follow: 
Table 3

Sample Selection Process

\begin{tabular}{clc}
\hline No. & \multicolumn{1}{c}{ Information } & Number of companies \\
\hline 1. & Total sharia life insurance companies and sharia unit \\
life insurance companies in 2019 & 30 \\
2. Sharia life insurance companies not in Indonesia & $(0)$ \\
3. Sharia life insurance companies that do not publish & $(8)$ \\
financial reports for 2012-2019 & Sharia life insurance companies that do not get \\
5ositive profit (loss) & (6) \\
& The selected company becomes the sample & 13 \\
\hline
\end{tabular}

Source: Data Processing Results

Based on the sample determination process above, a total sample size of 13 companies is obtained. The names of the companies sampled can be seen in the following table:

Table 4

List of Sharia Life Insurance Companies as Research Samples during 2012-2019

\begin{tabular}{cl}
\hline No. & \multicolumn{1}{c}{ Sharia Life Insurance and Life Insurance Companies That Have Sharia Units } \\
\hline 1. & PT. Takaful Keluarga \\
2. & PT. Asuransi Jiwa Syariah Al Amin \\
3. & PT. Prudential Life Assurance \\
4. & PT. Asuransi Allianz Life Indonesia \\
5. & PT. Asuransi Jiwa Sinar Mas MSIG \\
6. & PT. BNI Life Insurance \\
7. & PT. AXA Mandiri Financial Services \\
8. & PT. Asuransi Jiwa Manulife Indonesia \\
9. & PT. Panin Dai-Ichi Life \\
10. & PT. AlA Financial \\
11. & PT. Avrist Anssurance \\
12. & PT. AXA Financial Indonesia \\
13. & PT. Asuransi Jiwa Central Asia Raya
\end{tabular}

\section{Data Analysis Technique}

The data collected in this study were analyzed using regression analysis of more than two variables and processed using statistical program applications, namely E-views 10, with the analysis technique used was panel data regression. Panel data are data that consist of several variables such as cross-selection data, but also have time elements such as time series data, in other words panel data are combination of cross-sectional and time series data (Widarjono, 2018). In panel data regression, three data regression techniques are used, namely: general effects models, fixed effects models, and random effects model.

The tests used in this study include the t test (individual / partial parameter significance test), and $F$ test (simultaneous significant test) and the coefficient of determination $\left(R^{2}\right)$ to evaluate the best regression model.

This research was taken from 2012-2019, because in 2012-2019 when viewed from the data on the growth of the sharia-based insurance industry, the market share of Islamic insurance is still far below conventional insurance. This is both a challenge 
and an opportunity for sharia life insurance companies and sharia unit insurance companies to maximize their performance so that the role of sharia insurance in the Islamic economy and in national development is getting bigger. As said by Prof. Bambang Brojonegoro (Former Head of Bappenas) that sharia insurance has an important role in national development. This role is formed through investment financing by Islamic insurance companies.

\section{Hypothesis Testing}

\section{Partial / Significant Test (t test)}

The $t$ statistical test is used to measure the influence of one independent variable individually in explaining the variation of the dependent variable (Hasan, 2012). The basis for the decision is to compare the significant value calculated with a confidence level of $5 \%$. If the sig value is less than the level of confidence, it is concluded that the independent variable has a significant influence on the dependent variable.

\section{Simultaneous Test (Test F)}

The $\mathrm{F}$ test is a test of the overall model. This test is conducted to determine whether the independent variables simultaneously affect the dependent variable (Hasan, 2012). In testing the independent variable on the dependent variable, the $F$ test is carried out using a comparison between the significance value and the value ( $\alpha$ $=5 \%)$. Ho is accepted if F-statistic $\leq \mathrm{F}$-table, meaning that all variables together are not significant explanatory variables for the dependent variable. Meanwhile, $\mathrm{Ho}$ is rejected if the F-statistic > F-table, it means that all independent variables together constitute a significant explanation for the dependent variable.

\section{The Coefficient of Determination $\left(\mathbf{R}^{2}\right)$}

According to Nachrowi and Usman (2006), the determination coefficient is a proportion measurement of several variable versions depending on the average which can be explained by the independent variable or its predictor. In other words, the coefficient of determination $\left(R^{2}\right)$ or goodness of fit is a value that states the proportion or percentage of the total variation in the dependent variable $(\mathrm{Y})$ which can be explained by the explanatory variables together.

If the value of the determination coefficient is 1 , then the regression model can explain $100 \%$ of the variation in variable $Y$ and vice versa, if the coefficient of determination is 0 , the regression model cannot explain the slightest variation on variable $Y$, then the coefficient of determination is between zero and one $\left(0<R^{2}<1\right)$. The coefficient of determination also has a weakness, which is the number of independent variables that are included in the model. Therefore, this study uses the value of Adjusted $R^{2}$ to evaluate which regression model is the best. 


\section{RESULT AND DISCUSSION}

\section{Selection of Panel Data Regression Method}

To find out the appropriate method of the three regression models above, several tests are needed in determining the panel data regression estimation technique. According to Ghozali and Ratmono (2017) the tests that will be carried out to get the right model consist of the chow test and the Hausman test.

The chow test is used to choose between the Common Effect Model and the Fixed Effect Model based on the probability value ( $p$-value) $<\alpha=0.05$, then the research model used applies the Fixed Effect Model and if the probability value ( $p$ value) $>\alpha=0.05$, then the model used in this study is the Common Effect Model. While the Hausman test is used to determine the most suitable model between the Fixed Effect Model and the Random Effect Model based on the probability value ( $p$ value) $<\alpha=0.05$, the model used is the Fixed Effect Model and if the probability value ( $p$-value) $>\alpha=0.05$, then the model to be used in this study is the Random Effect Model.

From the results of Chow's test, it is obtained that the value of F-statistic > Ftable, it is concluded that the panel data model that can be used is the Fixed Effect Model. Following are the estimation results of the Fixed Effect Model:

Table 5

Fixed Effect Model Estimation Results

\begin{tabular}{cclcc}
\hline \multicolumn{1}{c}{ Variable } & Coefficient & Std. Error & t-Statistic & Prob \\
\hline C & 54208.74 & 9314.651 & 5.819728 & 0.0000 \\
X1 & 0.095714 & 0.032368 & 2.957030 & 0.0040 \\
X2 & 0.810489 & 0.241756 & 3.352507 & 0.0012 \\
X3 & 0.139821 & 0.038015 & 3.678081 & 0.0004 \\
Cross-section fixed (dummy Variables) & & & 106860.8 \\
R-squared & 0.948586 & Mean dependent var & 129866.8 \\
Adjusted R-squared & 0.939822 & S.D. dependent Var & \\
S.E of regression & 38418.65 & Durbin-Watson stat & \\
Sum squared resid & $1.30 \mathrm{E}+11$ & & & \\
F-statistic & 108.2391 & & \\
Prob (F-Statistic) & 0.000000 & & \\
\hline
\end{tabular}

Source: The data is processed using E-views 10

Based on the estimation results of the Fixed Effect Model, it can be concluded that the hypothesis testing is as follows:

\section{Hypothesis Testing}

\section{$T$ test results (significant test of individual/partial parameters)}

The provisions in the $\mathrm{t}$ statistical test are if $\mathrm{t}$-count $>\mathrm{t}$-table then $\mathrm{Ho}$ is rejected, thus $\mathrm{Ha}$ is accepted, with a significant value $\alpha=0.05$ (5\%), $\mathrm{df}=104$, t-table $=$ $1.98373(n-k=104-3=101)$. It can be said that there is an effect of the independent variable on the dependent variable partially. Following are the results of the $t$ test on the independent variables on the dependent variable: 
1. Based on table 5 of the variable of contribution income (X1), it is obtained that the value of $\mathrm{t}$-count $=2.957030>\mathrm{t}$-table $=1.98373$, from the results, it is seen that the contribution income (X1) partially has an influence on profits, so the hypothesis stating that Hol does not partially influence the profit of the sharia life insurance company is rejected.

2. In table 5 of the investment result variable (X2), it shows that the value of $t$-count $=3.352507>$ t-table $=1.98373$, it can be seen that the investment result $(\mathrm{X} 2)$ partially affects profit, so the hypothesis of $\mathrm{Ha} 2$ stating that investment results have a partial effect on the profits of the sharia life insurance companies is accepted.

3. Based on table 5 , the claim expense variable (X3) states that the claim expense (X3) partially affects profits, this can be seen from the value of $t$-count $=3.678081$ $>$ t-table $=1.98373$. So, it can be said that Ho3 is accepted, which means that the claim expense partially has an influence on the profit of the sharia life insurance company.

\section{F Test Results (Simultaneous Significant Test)}

The $F$ test examines the independent variables simultaneously (jointly) with the dependent variable, namely by comparing the F-statistic with the F-table, with the confidence level $\alpha=5 \%, k=3$ and $n=104$, then the F-table $=3.09$. Based on table 5 above, it can be seen that F-statistic $=108.2391>\mathrm{F}$-table $=3.09$ means that contribution income, investment result and claim expenses have a simultaneous (joint) effect on the profit of Islamic life insurance.

\section{Result of Determination Coefficient Test $\left(\mathbf{R}^{2}\right)$}

Based on the table 5 above, it can be concluded that:

1. The R (R-squared) correlation coefficient of 0.948586 indicates that there is a strong enough relationship between the independent and dependent variables (because it is close to number 1 )

2. The coefficient of determination (Adjusted $R^{2}$ ) of 0.939822 means that the dependent variable, namely profit can be explained or influenced by independent variables, namely contribution income, investment results and claims expenses of 93.98\% while the remaining $6.02 \%$ is explained or influenced by other variables not included in this study.

\section{Discussion}

\section{The Effect of Contribution Income on the Profit of Sharia Life Insurance}

In sharia life insurance, the contribution elements are different from general sharia insurance, the difference is because in sharia life insurance there are two elements of contribution, namely savings funds and tabarru' funds, while in general sharia insurance, there are only tabarru' funds in contributions paid by participants. 
This study is not in line with Sula's (2004) theory that contribution income is the biggest factor affecting insurance company earnings, therefore the determination of contribution has an important role in company strategy. Likewise, research is not in line with the research of Sastri et al. (2017) which states that premium income has a positive and significant effect on the profit of Islamic insurance. However, this study is in line with research of Wijaya (2013) and research by Reschiwati and Solikhah (2018) which state that partially premium income has a weak and insignificant relationship to profit.

Based on the description above, it can be seen that the contribution income partially affects profits. That is, the higher the contribution income obtained will affect the increase in profit. Therefore, the main factor for company profit is contribution income. To increase profit, it must be accompanied by adequate contribution income, preferably if the profit is low, this indicates a weak premium income.

It can be concluded that the contribution / premium is payment in the form of money paid regularly by the policyholder to the insurer as a result of insurance protection. Without premium payment, the insured will not receive compensation, the greater the amount of premium the company has, the greater the funds that the company can invest in the future, so that the greater the profit it will get.

Determining the amount of participant contributions plays an important role in the survival of the company and participants. Determination of participant contributions is expected to cover high losses and vice versa, namely by covering the same losses but low participant contribution rates (Indriani et al., 2019). According to Soedibjo and Fitriati (2009), the higher the participant's contribution or contribution / premium, the greater the amount of funds allocated for the insurance company's operational costs.

\section{The Effect of Investment Results on the Profit of Sharia Life Insurance}

Investment results are profits obtained in connection with investment activities carried out by investing or placing assets in the form of funds or assets. The profit generated is shared with the owner of the fund and the manager of the fund according to the ratio or profit sharing that has been mutually agreed upon. In sharia insurance, investment results are distributed to insurance participants as fund owners and insurance companies as fund managers.

Based on the research above, it can be seen that the investment returns partially have a significant effect on profits. The research is in line with the theory put forward by Ichsan (2014) which states that the movement of investment returns will affect the movement of insurance company profits. Furthermore, this research is in line with the research of Sastri et al. (2017), which states that investment results have a significant positive effect on insurance earnings. This research is also in line with Astria (2009), stating that with high investment yields, the company already has 
the expected profit or return, so that operational financing activities and the components borne by insurance companies can be resolved.

The profits earned by the investment will be included in the pool of participant funds and later reduced by "insurance expenses", namely claims and insurance premiums. This part of the profits is received by the company and will be used to finance the company's operations. Because the investment made by these insurance companies contributes directly to profits if the investment is profitable, it will affect profits, because investment is the only source of profit in Islamic insurance.

That is, if the investment results are high, the profits will be high and if the investment results are low, the profit will be low. The funds that are invested are large, so the investment results will be large, so that the company profits will be high. Therefore, the movement of investment returns will also affect the movement of the insurance company profit. The acquisition of higher investment returns shows the company's performance and ability to manage participant funds, so that it has a good impact on increasing the credibility and trust of participants in insurance (Istiqomah \& Gati, 2020).

However, if the investment return increases but is accompanied by an uncontrollable operating value such as a high claim, the investment return will be reserved in the claim, resulting in a net profit that is not optimal. For this reason, the company is expected to be able to control and minimize the greatest value in insurance company operations, such as claim payments (Nasution \& Nanda, 2020).

\section{The Influence of Claim Expenses on the Profit of Sharia Life Insurance}

Based on the research, the claim variable partially has a significant effect on earnings. This research is in line with the research of Saputro (2019) which states that claim expenses partially or simultaneously affect profits and Wijaya (2013) research that claims together make a small contribution to the amount of profit. However, this study is not in line with the research of Wulandari et al. (2019) stating that claim expense on profit has no effect on profit.

Claims are expenses that must be borne by sharia insurance whose payments come from tabarru' funds. Tabarru' funds are funds that the company will invest, so that if the claim is high, it will reduce the amount of funds that the company will invest, so that it will affect investment. And in the end, the investment becomes small, the growth of company assets reduces, so that the company profit level decreases (Dewi \& Witjaksono, 2015).

Likewise, the high total claim expense of an insurance company indicates the amount of funds spent to cover claims and benefits to the insured. If the total claim expense is higher than the contribution / premium income, then it is clear that the company's financial statements show a negative amount in the profit post or reduce the company's profit. 
Nainggolan, Soemitra,

\section{The Effect of Contribution Income, Investment Results and Claims Expenses on the Profit of Sharia Life Insurance}

Contribution income, investment results and claim expenses affect the profit of Islamic life insurance. This is shown in the F test, namely that the F-count > F-table, it can be concluded that contribution income, investment results and claim expenses simultaneously (together) affect the profit of Islamic life insurance. This research is in line with the research of Marwansyah and Utami (2017) which states that simultaneously showing that premium income, investment returns and claim expenses have a significant relationship to profits.

Management of the Islamic insurance industry should follow the pattern of mainstream management. It is just that, the sharia insurance industry in terms of products and operational mechanisms has been ensured to follow sharia principles (Sharia Compliant). In business, according to research Saputra et al. (2016): the consideration of pure risk through the mortality risk is applied by conventional life insurance and Takaful insurance to calculate the risk premium. Despite the similarity in calculating risk premium, both insurances have their own objectives. For instance, conventional insurance needs to know the risks that will be faced so that it can protect insurance participants and keep the insurance company from financial risk, by using pure risk or the life function of the mortality risk. On the other hand, risk consideration in Takaful insurance is carried out by sharing the fair value in the payment of compensation (Tabarru' funds) by insurance participants to the insurance company. In addition, the mudharabah contract is applied in Takaful insurance with the aim of eliminating the haram element in conventional insurance.

Kusairi et al. (2015) also show that Takaful insurance has a cheap premium compared to conventional insurance. However, Kusairi et al. (2015) suggest that the operational and administrative costs of Takaful insurance are higher than the annual premiums of conventional insurance. The benefits that can be obtained by Takaful insurance participants are also far better when juxtaposed with conventional insurance. This is because Takaful insurance offers a return on investment of $5 \%$, which is greater than the annual premium paid by the insured.

\section{CONCLUSION}

The findings of this study indicate that the contribution income factor has a partial effect on the profit of Islamic life insurance, the higher the contribution income obtained, it will affect the increase in profit, this is because the main factor of company profit is contribution income. To increase profit, it must be accompanied by adequate contribution income, preferably if the profit is low, this indicates a weak premium income. Therefore, determining the amount of participant fee or contribution plays an important role in the survival of the company and the participants. Likewise, the investment results factor partially affects the profit of Islamic life insurance, meaning that if the investment yield is high, the profit will be 
high, and vice versa. If the funds invested are large, the investment results will be large, so that the profits will be high. Likewise, the claim expense factor partially affects the profit of Islamic life insurance, this is because the claim is an expense that must be borne by Islamic insurance whose payments come from the tabarru' funds. Tabarru' funds are funds that the company will invest, so that if the claim is high, it will reduce the amount of funds that the company will invest, so that it will affect investment. And in the end, the investment becomes small, the growth of company assets decreases, so that company profit level is small, and if the total claim expense is higher than the contribution / premium income, then it is clear that the company's financial statements will show a negative amount in the profit post or reduce the company's profit.

This study has several limitations, namely research objects and variables. This study uses 13 samples of sharia life insurance companies so that the expected results are still not optimal, the independent variables in this study are only partial, so that further research projects must add an independent variable that theoretically affects the profits of Islamic life insurance companies. This research analysis technique uses panel data regression; it is expected that future studies apply different methods in processing the data.

Judging by the fact that there are sharia insurance companies that have not published their financial reports in a transparent manner, it is advisable for insurance companies to publish their financial reports that are complete and transparent to all. And there are still many people who are not familiar with insurance, especially sharia insurance, it is advisable for sharia insurance companies to be more aggressive in introducing them to the community, especially rural communities, so that the growth of Islamic insurance users becomes bigger las in conventional insurance growth.

This research will provide education to the public about insurance, especially sharia insurance and provide public awareness of the importance of insurance and to know more about the obligations and rights that must be obtained.

\section{REFERENCE}

Ambarwati, S., \& Hasib, F. F. (2018). Pengaruh Ukuran Perusahaan, Hasil Investasi dan Profitabilitas Terhadap Solvabilitas Asuransi Syariah Di Indonesia Periode 20122016. JEBIS, Vol. 4, No. 2, (Juni - Des). https://dx.doi.org/10.20473/jebis.v4i2.9807pp91-102

Amrin, A. (2006). Asuransi Syariah: Keberadaan dan Kelebihannya di Tengah Asuransi Konvensional. PT. Elex Media Komputindo Gramedia.

Amrin, A. (2011). Meraih Berkah Melalui Asuransi Syariah Ditinjau dari Perbandingan dengan Asuransi Konvensional. PT. Elex Media Komputindo Gramedia. https://books.google.com/books?hl=en\&lr=\&id=1YVKDwAAQBAJ\&oi=fnd\&pg =PP1\&dq=Amrin,+A.+(2011).+Meraih+Berkah+Melalui+Asuransi+Syariah.+Jak arta:+Elex+Media+Komputindo.\&ots=4PpupbNkaB\&sig=8qU8PAXRoKSYLSrLF o8pIDpUAeE 
Astria, D. (2009). Analisis Faktor-Faktor yang Mempengaruhi Laba PT Asuransi Takaful Keluarga. Institut Pertanian Bogor.

Bayinah, A. N., Mardian, S., Mulyati, S., \& Maulidha, E. (2017). Akuntansi asuransi syariah. Salemba Empat.

Ciurel, V. (2000). Insurance and Reinsurance: Abroad Theoritical and Practical International. Editura All-Beck.

Dewi, K. V., \& Witjaksono, A. (2015). Evaluasi Pengakuan Pendapatan dan Beban Atas Dana Tabbaru' dan Dana perusahaan pada Asuransi PT AJB BumiPutera. BINUS.

Ghozali, I., \& Ratmono, D. (2017). Analisis Multivariat dan Ekonomretika: Teori, Konsep, dan Aplikasi dengan EViews 10. Badan Penerbit Universitas Diponegoro.

Harahap, S. S. (2008). Kerangka teori dan tujuan akuntansi syariah [Theoretical framework and objective of Islamic accounting]. In Pustaka Quantum. Pustaka Quantum.

Hasan, I. (2012). Analisis Data dengan Statistik. Bumi Aksara.

Hasbi, H., \& Suryawardani, B. (2013). Sistem Peringatan Dini Sebagai Pendukung Kinerja Perusahaan Asuransi Syariah. Jurnal Keuangan Dan Perbankan, 17(2), 243-252.

Hendryadi, S. (2015). Metode Riset Kuantitatif Teori dan Aplikasi pada Penelitian Bidang Manajemen dan Ekonomi Islam. Pramedia Group.

IAI. (2016). Standar Akuntansi Keuangan Syariah Per 1 Januari 2017. Ikatan Akuntan Indonesia.

Ichsan, N. (2014). Pengantar Asuransi Syariah. Gaung Persada Pres Group.

Indriani, R., Canggih, C., \& Rusmita, S. A. (2019). Efficiency Determinants of Islamic Insurance in Indonesia. The 2nd International Conference on Islamic Economics, Business, and Philanthropy (ICIEBP) Theme: "Sustainability and Socio Economic Growth, Publisher KnE Social Sciences, 175-182.

Istiqomah, A., \& Gati, V. (2020). Risk Effect on Contribution of Participants in Sharia Insurance Indonesia. Jurnal Ekonomi Dan Bisnis Islam (Journal of Islamic Economics and Business), 6(1), 1. https://doi.org/10.20473/jebis.v6i1.18254

Kusairi, S., Saputra, J., \& Sanusi, N. A. (2015). An Understanding the Determination of Life Insurance Premium: Shariah Compliant in the Islamic Insurance Concept and Practice. ASEAN Consortium on Department of Economics Conference (ACDEC), January, 10.

Marwansyah, S., \& Utami, A. N. (2017). Analisis Hasil Investasi, Pendapatan Premi, Dan Beban Klaim Terhadap Laba Perusahaan Perasuransian Di Indonesia. JURNAL AKUNTANSI, EKONOMI Dan MANAJEMEN BISNIS, 5(2), 213. https://doi.org/10.30871/jaemb.v5i2.533

Nachrowi, D., \& Usman, H. (2006). Ekonometrika untuk Analisis Ekonomi dan Keuangan. Lembaga Penerbit Universitas Indonesia.

Nasution, N. H., \& Nanda, S. T. (2020). Pengaruh Pendapatan Premi , Hasil Underwriting, Hasil Investasi dan Risk Based Capital terhadap Laba 
Perusahaan Asuransi Umum Syariah. Jurnal IImiah Ekonomi Dan Bisnis, 17(1), 41-55.

Otoritas Jasa Keuangan Indonesia. (2019). Statistik Perasuransian Insurance Statistics 2018. Jakarta: Otoritas Jasa Keuangan, Republik Indonesia, (Juli).

Purwosutjipto. (1999). Pengertian Pajak Hukum Dagang Indonesia. Djambatan.

Puspitasari, N. (2015). Manajemen Asuransi Syariah. UII Press.

Reschiwati, \& Solikhah, R. P. (2018). Random Effect Model : Influence of Income Premium, Claim Cost and Underwriting Results on Net Income in Insurance Company in Indonesia : Case Study of Insurance Company. International Journal of Modern Trends In Business Research (IJMTBR), 1 (3 (September, 2018)), 1-17.

Salim, A. (2007). Asuransi dan Manajemen Risiko. Rajawali Pers.

Saniatusilma, H., \& Suprayogi, N. (2015). Manajemen Risiko Dana Tabarru' PT. Asuransi Jiwa Syariah Al Amin. Jurnal Ekonomi Syariah Teori Dan Terapan, 2(12). https://doi.org/10.20473/vol2iss201512pp1002-1018

Sanusi, A. (2011). Metode Penelitian Bisnis. Salemba Empat.

Saputra, J., Kusairi, S., Sanusi, N. A., \& Abdullah, Y. (2016). An Analysis of Determination for Life Insurance Premiums : The Concept and Practice of Conventional and Islamic Life Insurance ( Family Takaful ). Malaysian Journal of Applied Sciences, 1(2), 41-51.

Saputro, F. B. (2019). Pengaruh Risk Based Capital Dan Beban Klaim Terhadap Laba Pada Perusahaan Asuransi Jiwa Periode 2014 - 2016. Jurnal SeMaRak, 1(3). https://doi.org/10.32493/smk.v1i3.2253

Sastri, I. A. I. P., Sujana, E., \& Sinarwati, N. K. (2017). PENGARUH PENDAPATAN PREMI, HASIL INVESTASI, DAN RISK BASED CAPITAL TERHADAP LABA PERUSAHAAN ASURANSI (Studi pada Perusahaan Asuransi yang Terdaftar di Bursa Efek Indonesia Periode 2015-2018). Jurnal Ilmiah Mahasiswa Akuntansi UNDIKSHA, 7(1). https://doi.org/10.23887/jimat.v7i1.9409

Sholihin, A. I. (2010). Buku Pintar Ekonomi Islam. PT Gramedia Pustaka Utama.

Soedibjo, S., \& Fitriati, R. (2009). untuk Mencapai Titik Impas dengan Pendekatan Model Profit Testing. Jurnal Ilmu Administrasi Dan Organisasi, 16, 59-67.

Soemitra, Andri. (2009). Bank dan Lembaga Keuangan Syari'ah. Perdana Media Group.

Sula, M. S. (2004). Asuransi Syariah (Life and General) : Konsep dan Sistem Oprasional. Gema Insani.

Syahatah, H. (2006). Asuransi dalam Perspektif Syariah. Amzah.

Widarjono, A. (2018). Ekonometrika Pengantar dan Aplikasinya Disertai Panduan EViews. UPP STIM YKPN.

Wijaya, R. P. (2013). Pengaruh Pendapatan Premi, Hasil Investasi, dan Klaim terhadap Laba (Studi Kasus pada Perusahaan Asuransi Jiwa yang Memiliki Unit Syariah) [Universitas Pendidikan Indonesia]. http://repository.upi.edu/4632/

Wulandari, J. R., Wiyono, W., \& Rizal, N. (2019). PENGARUH PREMI, KLAIM, 
INVESTASI, DAN UNDERWRITINGTERHADAP LABA PERUSAHAAN ASURANSI JIWA SYARIAH DI INDONESIA PERIODETAHUN2013-2017. PROGRESS

Conference, 2(July 2019), 79-85.

Yanggo, H. T. (2003). Asuransi Hukum dan Permasalahannya. AAMAl, 8(12). 